\title{
ELECTRICITY AND GAS INSPECTION SERVICES IN OTTAWA
}

$\mathrm{T}$ WE annual report of the Electricity and Gas Inspection Services of Ottawa for the fiscal year, ended March 31, 1939, has been published (Ottawa: King's Printer. 25 cents). It is addressed to the Department of Trade and Commerce, and describes the activities of the Electricity and Gas Inspection Branch from March 1938 until February 1939, with the work performed during the previous year. So far as the Electricity and Gas Inspection Services are concerned, the work performed creates a record. The total revenue was $£ 2,400$ more than the preceding year and there were 21,000 more meters tested. A decrease in the surplus is mainly due to the fact that the salaries of the headquarters staff are included in the statement for the first time. The amounts required to cover rent, fuel and furniture for the Services as a whole are not included in this summary. The expenditures incurred in the administration of the Electricity and Fluid Exportation Act are included in the amount charged against electricity inspection. This amounted to about $£ 40$.

Calorific tests of manufactured gas were made throughout the Dominion and the average heating value was found to be 489 B.T.U. per cubic foot. The standard required is 450 B.T.U. per cubic foot. The amount of natural gas supplied throughout Canada during this period was approximately 32,000 million cubic feet, an increase of $5 \frac{1}{2}$ millions over last year. The total number of meters in service on March 31, 1939, was approximately two million, an increase of nearly 60,000 over the preceding year.

The periodic calibration and checking of the inspection standards, supplied to the various inspeators throughout Canada for outside companies and other departments of the Government, is performed in the laboratories of Ottawa, Winnipeg and Vancouver. The expenditure on electricity inspection was $£ 55,000$ and on gas inspection was $£ 15,000$.

The number of kilowatt-hours of electrical energy produced for export during the fiscal year 1938-39 was 1,940 million, an increase of 100 million over the preceding year. The number of kilowatt-hours produced for use in Canada by the exporting companies was 3,100 million electric units, as compared with 4,132 million during the previous year. The revenue collected by virtue of the export duty of 0.03 cent per electric unit shows a slight increase over the preceding year.

The Range Oil and Gas Company exported approximately 289 million cubic feet of natural gas from the Rogers Imperial structure in southern Alberta during the past year; and the Vanalta Oils, Ltd., exported approximately 27 million cubic feet from the Red Coulee field, also in southern Alberta. No revenue, except the licence fee, ten pounds for each licence, is obtained from this export.

\section{THE McCOMB-ROMBERG SEISMOMETER}

$\mathrm{M}$ ODELS of this new tilt-compensation seismometer have recently been placed in the new seismographic station of the Nebraska Wesleyan University in Lincoln, Nebraska, in the Chicago Seismograph Station, and in Salt Lake City ("New Instruments and Equipment at Coöperative Seismograph Stations of the United States Coast and Geodetic Survey", J. H. Nelson and H. E. McComb, Bull. Seis. Soc. Amer., 29, No. 4, 549-588; Oct. 1939). A few of its salient features are as follow: It rests on a one-piece brass plate having point-slot-plane positions for the seismometer footscrews. Around the edge of this base plate is a ploughed slot in which the edges of the metal cover rest Air currents and dust are effectively kept away from the boom and optical system. The column is relatively short and well braced against possible side sway. At the top of the column a worm-driven windlass provides easy and accurate adjustment of the length of the supporting wires from which the steady mass is suspended. The boom, a duralumin rod about 12 in. long has at one end a sapphire jewel which rests against a steel pivot mounted in the bottom of the column, and at the other end a vane of electrolytic copper which floats in the field of a cobalt steel permanent magnet. A rough auxiliary pivot with slow-motion screw mounted on the column to work against a brass cup on the boom is provided for protecting the main pivot and jewel at times of installation and adjustment. The mass is of brass, weighing $2,550 \mathrm{gm}$. The boom, damping vane and oil cup weigh about $130 \mathrm{gm}$. The magnet is mounted on guides and may be readily removed at times of determining free period and recording decay curves. The air gap may be easily adjusted by means of a knurled-head micrometer screw.

The optical system of multiplying lever and mirrors gives a nominal magnification of about 350 . The seismometer cover is of thin sheet aluminium, provided with doors for adjustments and a glass window set so as to reflect stray light downwards and not into the optical system. Both the north-south and east-west components record on one Henson recorder. The speed of the drum is $15 \mathrm{~mm}$. per minute (one revolution per hour), translating about $5 \mathrm{~mm}$. per revolution. It is driven by a 60-cycle 110-volt synchronous motor through a train of cut gears. A single seismogram 12 in. $\times 36$ in. in size is obtained. The east-west component records directly whereas the north-south component operates by reflection from a large first-surface mirror which gives no distortion. 